DOI: 10.2478/auseur-2019-0013

\title{
Economic Relations of Hungary and India: Seeking Ways to Be Better Than 'Just Good'
}

\author{
Péter GORECZKY \\ Senior Analyst, Institute for Foreign Affairs and Trade, Hungary \\ e-mail: peter.goreczky@ifat.hu
}

\begin{abstract}
As for Hungary, core motivation factors in building economic relations are boosting the export performance of SMEs and attracting FDI projects of high added value. India as an export market is definitely a challenging target for Hungarian companies as geographic distance, cultural differences, infrastructure, and regulatory barriers can all be considered as pull-back factors. Nevertheless, an innovative product and international experience combined with the involvement of a local partner can result in success. India is one of the most important Asian investors in Hungary with a very diverse FDI stock in terms of economic sectors. Indian investors are mostly satisfied with the business environment in Hungary; however, labour shortage is considered as a challenge to be addressed. Compared to building relations with China, India today receives less attention in Hungary. However, both governments could do a lot more in accelerating the interactions of Hungarian and Indian businesses and creating more opportunities to raise economic relations to the next level.
\end{abstract}

Keywords: Hungary, India, economic relations

\section{Introduction}

Today, there is wide consensus regarding that mostly economies in the East will drive the global economic growth in the next decade. China is already considered to be an economic superpower, which makes every effort to reshape the global economic system. However, besides China, there are other countries and regions in Asia that emerge as economic powerhouses of the future. India is definitely one of the leading candidates in that terms - due to its size and population, the country will surely become a leading economy at a global level. Being an open, trade- and investment-driven economy, Hungary has to pay attention to these changes of the global economic landscape and react accordingly. The fact that the gravity of economic growth had shifted from the West to the East was reflected in the Hungarian Government's perception - as Prime Minister Viktor Orbán drew 
up already in 2010: 'an Eastern wind blows in the global economy' (Magyari 2010). Governmental communiqués in the last couple of years still reiterated this thesis, emphasizing that in the new industrial era there was a competition not only for Western capital but also for capital from the East, and more and more companies from the Far East were searching for new European locations to place their production capacities. ${ }^{1}$ Besides this, booming population combined with fast GDP growth that characterizes certain regions of Asia create new market opportunities for Hungarian exporters.

The aim of this paper is to analyse the current state and future prospects of economic relations between India and Hungary from the perspective of Hungary's interests in external economics. For that purpose, the paper builds on first-hand information received through interviews with representatives of the Hungarian business sector and a major Indian investor company in Hungary.

\section{Core Interests of Hungary in External Economic Relations Today}

From 2011, it has been a frequently cited strategic goal in the Hungarian Government's communication that the country should develop to be the manufacturing centre of Central and Eastern Europe. One of the goals of the 'Made in Hungary' concept was the reduction of unemployment, which required the attraction of job-creating investment projects. Accordingly, investment promotion has been considered a top priority in the governmental external economic activities. Partly due to governmental efforts and partly due to favourable external conditions, the country managed to secure a number of manufacturing investment projects in the past couple of years.

As of early 2017, a shift could be noticed in the focus of the strategic goals communicated by the Ministry of Foreign Affairs and Trade. The 'Invented in Hungary' vision has emerged, and it has been articulated that the country had to attract research, development, and activities of high added value through foreign direct investment projects. This shift in goals and in the focus of communication indicates that the further development of the Hungarian economy requires moving up in the global value chain and becoming - at least partly - an innovation centre.

Besides placing investment promotion in focus, the Hungarian Government has also declared export development as a pillar of the country's external economic policy. Being an open economy trade, the GDP ratio of Hungary is traditionally high; however, the country's export is concentrated both in terms of geographies (almost $82 \%$ of the country's export goes to EU Member States) and product structure, which results in a substantial level of exposure. Therefore,

1 The Hungarian Government's communication. 
diversification is an important motivation factor in building the country's external economic relations.

In 2014, an institutional triangle was created to support the foreign-trade focused foreign policy of the Hungarian Government. The triangle covers the fields of investment promotion, trade development, and export financing as well. Trade development and export financing efforts mainly concentrate on Hungarian small and medium-sized enterprises, the company group that provided job for twothirds of employees in the private sector in $2016 .^{2}$ In contrast with its importance in the field of employment, the SME sector accounts for only $20 \%$ of the total Hungarian merchandise exports. Despite favourable tendencies recently, only a small proportion of Hungarian SMEs are engaged in export activity. The number of export-capable Hungarian companies is still below the per capita index of EU Member States. The reason behind is that the productivity of Hungarian SMEs lags behind that of their Western European and even regional counterparts. ${ }^{3}$

In simple terms, the core interests of Hungary in external economic relations are to attract high added value FDI and to enhance SME export. These are the core motivation factors in building economic relations with every foreign country.

\section{Doing Business in India from a Hungarian Perspective}

As trade-related statistics highlight, Hungarian export to India increased by almost 50\% between 2014 and 2018, although from a relatively low base. Similarly to other export destinations, the transactions of multinational companies account for the largest part of the export to India. Exact statistics for this ratio are not available; in general, the share of small and medium-sized enterprises in Hungary's total national export is estimated to be around $20 \%$. This ratio is probable also in the case of India. As the business activity of multinational enterprises is impacted by several factors, including global and sectorial trends, it is hard to predict whether this increase in Hungarian export to India is a start of a long-term upswing. The export activity of multinationals is mainly out of the influence zone of local governments; therefore, export development efforts are usually concentrated on small and medium-sized enterprises. India as an export market should be analysed from that perspective as well.

2 Source: Hungarian Central Statistical Office 2017.

3 Source: Hungarian National Bank. 
Table 1. Hungary's trade with India (EUR million) ${ }^{4}$

\begin{tabular}{lccccc}
\hline & $\mathbf{2 0 1 4}$ & $\mathbf{2 0 1 5}$ & $\mathbf{2 0 1 6}$ & $\mathbf{2 0 1 7}$ & $\mathbf{2 0 1 8}$ \\
\hline Import & 286.7 & 329.2 & 345.3 & 391.7 & 388.0 \\
\hline Change (\%) y-o-y & $104 \%$ & $115 \%$ & $105 \%$ & $113 \%$ & $99 \%$ \\
\hline & & & & & \\
\hline Export & 157.3 & 193.4 & 168.6 & 203.9 & 235.2 \\
\hline Change (\%) y-o-y & $97 \%$ & $123 \%$ & $87 \%$ & $121 \%$ & $115 \%$ \\
\hline
\end{tabular}

\section{Barriers of Hungarian SME Export to India}

Surely, Hungarian SMEs have to face a number of challenges when targeting the Indian market. Geographic distance is a major bottleneck as most export-capable Hungarian SMEs are active in the region close to the domestic market. In most cases, companies are not willing to make the first step and travel to India in order to explore market opportunities because of high travelling costs. At this point, the Hungarian state could offer financial support via tenders for those companies that are interested in presenting themselves in business events and trade shows in India. The Indian Embassy in Hungary could also organize workshops, even in the countryside, in order to promote India for Hungarian businesses.

Infrastructure and regional differences could also be an issue for Hungarian enterprises when planning business operations in India. By European standards, road and transport networks are underdeveloped, and it is hard to perceive the country as an integrated market due to substantial differences in the business environment of federal states. Doing business beyond Delhi and Mumbai seems even more challenging; in a realistic approach, Hungarian firms are far from being capable of locating business activity to the Indian countryside. However, both Delhi and Mumbai have a larger population than Hungary itself, and thus they provide a sizeable market for Hungarian companies.

Initiated by the Indian Government in 2014, the 'Make in India' programme and its consequences also raise the bar for Hungarian companies to do business in the country. Import restrictions imply substantial barriers for market access, while regulations on public procurement tenders also protect local players. Exporting semi-finished products and doing the assembly in India could be a way of securing local added value. The Indian Government's objective to support local manufacturing and local added value is reasonable from the perspective of industry development and job creation. Nevertheless, very few Hungarian companies tick all the boxes when it comes to locating production activity in a distant and culturally different country. 
Traditionally, agriculture is a main pillar of the Hungarian economy and a sector in which small and medium-sized enterprises are seeking export opportunities. In this field, the potential for increasing the Hungarian SME export looks poor for several reasons. India strongly protects its domestic market through tariffs and non-tariff barriers such as import permissions resulting in a low level of agricultural import even from the European Union as a whole.

Based on Hungarian expert experiences, making the list of countries that are permitted to export a given product to India is a challenging and long process, which may take years of diplomatic negotiations. Regulations may restrict the import in several ways. An example for this practice was that Indian authorities required that the pest control of imported agricultural products had to be carried out by using an agent that was banned in the European Union 10 years ago. Therefore, such requirement is physically impractical for a Hungarian company. Moreover, the Indian Government supports local producers through several programmes which would make Hungarian products less competitive in the market. Religious traditions in gastronomy also limit the range of agricultural products that can be popular in the Indian market. As a consequence of all these difficulties, in early 2019, there were no such talks ongoing between India and Hungary in terms of agricultural product lines, and no Hungarian companies were showing interest in agricultural export to India.

Comparing to China, it looks that building business relations is in its initial phase. The main reason behind it is that China has been in the focus of the Hungarian Government's Eastern Opening strategy, and this was reflected at the business level as well. Despite that China is also considered to be a tough market for Hungarian enterprises, businessmen perceive India to be even more challenging in terms of identifying the appropriate partner. Establishing a database of potential business partners with the contribution of the Indian government could provide valuable support for Hungarian enterprises. Organizing more forums and business-to-business meetings as well as sharing best practices could also contribute to taking business relations to a higher level.

It is difficult to identify an economic sector or business segment in which Hungarian SMEs clearly have promising opportunities. Generally, with niche technologies that are equally competitive in other markets, they may have a chance in India as well. In the case of Hungarian enterprises, this could mean water treatment and purification technology, hospital and medical equipment with both software and hardware content, and agricultural and fruit-processing technology. According to the experiences of Hungarian trade diplomats, those Hungarian SMEs have the chance to enter successfully the Indian market that offer products of high added value. This enables the exporter to use air transport and decrease delivery time substantially. 
A regular flight between the two countries would boost business ties as well. In 2013, the media reported that budget airline Wizzair might have organized a flight between Budapest and Mumbai through Dubai. However, a year later, the company reported that the plan had been cancelled. ${ }^{5}$ In late 2018, the Hungarian Government revealed in a press conference that Turkish Airlines would be launching a direct air passenger service between Budapest and Mumbai. According to the announcement, the required negotiations were about to begin immediately with Turkish Airlines and the Indian authorities. ${ }^{6}$

\section{Case Study: Logipix Technical Development Ltd. ${ }^{7}$}

Logipix Technical Development Ltd. is a privately held company established in 1996 in Budapest. Initially, the primary profile of the company was to develop and produce access control systems. Later, the company shifted its focus and started creating complex security surveillance solutions. Today, the main profile of the company is to provide IP-based, high-end video surveillance solutions. Over the years, Logipix has developed to become one of the most innovative developers and manufacturers of end-to-end security solutions in the world.

According to the CEO of Logipix, the company provides cameras with the highest resolution worldwide. Today, more than 50 development engineers are employed in the company's headquarters in Budapest. Logipix represents itself in 8-10 international trade shows per annum.

The basis of the company's successful operations in India was the considerable experience in doing business at an international level. Prior to entering the Indian market, Logipix has already made notable footprints in the Middle East and Russia. The company has deployed stadium video surveillance systems in 65 stadiums worldwide, including the Luzhniki Stadium, the national stadium of Russia, located in its capital city, Moscow. It was named the main stadium of 2018 FIFA World Cup and hosted 7 matches of the tournament, including the opening match and the final.

The company's business contacts with India commenced as a result of a meeting at a trade show. Logipix started to cooperate with an Indian distributor; however, the local partner could not deliver real sales levels. Nevertheless, the Hungarian management recognized the potential of the Indian market and founded a local subsidiary with local staff. According to the company's management, this was inevitable in order to manage differences in communication and to understand local needs. Logipix considers both of these to be crucial in achieving success in the Indian market. Due to cultural disparities and the pure size of the country,

5 Source: AIRportal.hu 2014.

6 Hungarian Government's communication.

7 Based on an interview made with the Logipix management on 28 March 2019. 
selling products or services in India requires a different approach than in Europe. Today, a staff of 11 is employed at the Indian subsidiary of Logipix, who are engaged mostly in sales, sales support, and technical assistance.

In line with the 'Make in India' initiative, local added value is a precondition for successful participation in large-scale public procurement tenders. References from Europe do not mean a competitive advantage due to the totally different environmental conditions. For the time being, Logipix does not operate a local assembly plant as it would result in higher manufacturing costs. In most cases, financial and delivery requirements can be fulfilled through the assistance of local partners. Nonetheless, in the case of successful participation in such tenders, Logipix would consider transferring technology and assembly activity to India. One of the key milestones of the company's business operations in India has been the establishment of the video monitoring system at Mumbai International Airport. Following some negotiations at a trade show, a consultant presented the company's airport video monitoring solutions to the management of Mumbai Airport. Logipix was requested to launch a pilot system that was operational at the airport for one year. Afterwards, a call for tender was published in which Logipix managed to overcome its competitors both in terms of price and technical parameters. This time, local manufacturing was not a precondition. However, the company explains that in most cases it is very hard to compete with big companies that can supply extreme large-scale systems for which small companies like Logipix do not have a capacity.

The company also managed to become a supplier of the traffic video surveillance system in Delhi. Logipix succeeded in finding a technical solution for a very concrete problem - namely, the visibility of home-made number plates by traffic surveillance cameras. The key factor of success was that the company could provide a solution for specific local conditions and customer demand.

The experiences of Logipix could serve as guidelines for further Hungarian small and medium-sized enterprises approaching the Indian market. First, the characteristics of the product are of key importance. Entering the Indian market with a simple copy of an existing product will probably lead to a market failure as sooner or later the customers will find cheaper sources of purchase in China or Southeast Asia. Therefore, the innovative character of the product is crucial. The main question that should be raised when writing the market strategy is: how could the company create value for the locals? For example, it is a strategic goal of the Indian economy to create new jobs, wherefore appliances that do not need human operators may not be preferred in public tenders. Realizing that, Logipix offers a traffic surveillance solution with manual module as well.

A promising product will not necessarily be followed by success in the external markets. Corporate structure and human capital should be developed intentionally in the spirit of selling abroad. This means that colleagues in key positions should 
be 'export-compatible' with adequate language and marketing skills. Domestic business opportunities should be grabbed also in a manner that carries the vision of going international in the future. Focusing exclusively on profit is not a good approach in developing a globally successful product. In India, it is a further challenge that products should come at a relatively low level of prices due to the Chinese competitors. Altogether, the experiences of Logipix underline that only Hungarian SMEs with a track record in international environment will have real chances to enter the Indian market. Besides that, the company should be able to finance pilot projects, the participation in trade shows, and the payroll of local staff for years before achieving considerable sales levels. Definitely, it is a major obstacle for most of the Hungarian small and medium-sized enterprises.

\section{Case Study: Gedeon Richter Plc. ${ }^{8}$}

In 2004, the largest Hungarian pharmaceutical manufacturing company decided to establish a production unit in India. The main reason behind the decision was that the company's active pharmaceutical ingredient (API) production capacity in its Hungarian sites was insufficient for future demand. As alternatives to the expansion of the Hungarian sites, the company evaluated the scenario of setting up a manufacturing unit and the possibility of establishing a joint venture in China or India. Analysing the costs of the project alternatives, the company opted for establishing a new joint venture. India was selected as the location against China due to the higher level of English-language skills and the democratic political system. A special argument for selecting India was that Richter had had a relationship with Themis Medicare Ltd., a Mumbai-based local pharmaceutical company.

The joint venture was owned in $51 \%$ by Richter and in $49 \%$ by Themis, which company possessed the suitable plot in a local industrial park that was offered as a contribution in the new company. The implementation of the facility lasted for 18 months - a substantially shorter period compared to the scenario of setting up the facility in Hungary. The remarkable speed of permitting procedures and construction works was primarily the result of that Richter had an experienced local partner a factor that the company considers to be of key importance in the success of its operations in India. According to the company's calculations, the implementation costs were ca. 80\% lower in India than they would have been in Hungary.

Located in Vapi, 160 kilometres from Mumbai, trial production in the new facility started in 2006. The multipurpose plant has been inspected several times by a number of European authorities. In the facility, 15 different APIs and 80 intermediate products are manufactured that are transported to Hungary, where finished drugs are prepared and then sold worldwide. As for cost advantages, despite rising wage levels, the salary of a blue-collar worker in the facility is still 
one third or a quarter of a worker's earnings in Hungary. In the case of managers and skilled employees, the difference from European wage levels is minor.

One of the biggest challenges for the joint venture is the extremely high fluctuation rate of blue-collar workers in the facility. Richter anticipates that conditions will not change significantly in these terms, wherefore they concentrate on retaining key employees and managers in the long run. Furthermore, compliance with the tightening environmental regulations is a field of additional efforts.

\section{Investment Relations}

\section{Hungary as an Investment Location}

Located in the heart of the continent, the favourable geographic location is one of Hungary's main attractions concerning foreign direct investments. Being a major transport junction in Central and Eastern Europe, the country is an ideal location for regional distribution centres. In the last couple of years, the country has made efforts to position itself to be a gateway to the European Union for companies from eastern countries. Hungary has one of the highest road densities in Europe, which also makes the country attractive for foreign companies. Its extensive railway network is also a strong argument for potential investors in logistics. In addition, Hungary offers the political and economic stability of being an EU Member State.

When it comes to location selection for foreign direct investments (FDI), the availability of a qualified and cost-effective labour pool is always high on the agenda. This factor has been the cornerstone of Hungary's competitiveness in FDI attraction since the early 1990s. Today, wage differences are still remarkable compared to Western European countries; however, Hungary and other countries in the region have been reporting historically low unemployment rates recently. (According to the Hungarian Central Statistical Office, an unemployment rate of $3.4 \%$ was recorded in Hungary in May-July 2019.) Naturally, substantial disparities can still be observed when comparing the more developed Western regions and the Budapest metropolitan area to the north-eastern and southern parts of the country. Nevertheless, the availability of skilled labour force in general is an issue today and is going to be the key challenge for any foreign investor, including Indian companies. Realizing the labour market trends, the Hungarian Government has already introduced measures to stimulate labour mobility; yet the effectiveness of these actions remains to be seen.

The basics of the Hungarian taxation system are in line with Western European standards. A single-rate personal income tax was introduced in 2013, which is currently $15 \%$. Boosting the competitiveness of the Hungarian corporate taxation 
system, the government reduced the tax rate to $9 \%$, which is the lowest in the European Union. Based on the EU legislation, Hungary offers a wide range of tax allowances and cash incentives for companies locating FDI projects for the country. During the period of 2017-2018, the social contribution tax rate of $27 \%$ payable by the employers was reduced to $19.5 \%$ in two steps.

\section{Major Indian Investors in Hungary}

So far, the Hungarian Government has signed strategic partnership agreements with three Indian companies, namely: Tata Consultancy Services (2013), CG Electric Systems Hungary (2013), and Samvardhana Motherson Refletec (2015).

With more than 2,300 experts, Tata Consultancy Services (TCS) operates one of the biggest service centres in Hungary. TCS Hungary offers the widest range of foreign language services in the region, covering more than 30 languages. Established more than 15 years ago, TCS Hungary has been the company's first Global Delivery Centre outside of India, employing well-trained engineers, economists, information experts, and developers with multilingual capability and university education. With a full range of solutions, the Hungarian facility supports Hungarian, European, and global clients. As a completion of its latest Hungarian investment project, TCS inaugurated their expanded service centre in Budapest in April 2017. ${ }^{9}$

CG Electric Systems Hungary (formerly Ganz - manufacturer of the world's first transformer in 1885) is a high-tech company with a strong reputation for global engineering capabilities in the area of power transformers, GIS switchgear and rotating machines, turnkey projects, and solutions for HV substations and power engineering. At present, the Company has over 800 employees and operations in three locations in Hungary.

In 2015, the project of Samvardhana Motherson Peguform (SMP) belonging to the Samvardhana Motherson Group (SMG) received the 'Largest Greenfield Investment of the Year Award' in Hungary. The project of the Indian-based automotive supplier has established a bumper manufacturing plant in Kecskemét in an area of 96,000 square metres. Based on an individual government decision, the Hungarian government provided subsidy to the SMP for the development rated as a high-priority project for the national economy, which created about half a thousand jobs. ${ }^{10}$

Between 1 January 2014 and 12 December 2018, the governmental investment promotion system was engaged in 15 investment projects, in which Indian companies opted for Hungary. Altogether, these projects accounted for an investment volume of EUR 787.6 million and created 3,500 new jobs.

9 Source: Hungarian Investment Promotion Agency 2017a.

10 Source: Hungarian Investment Promotion Agency 2017b. 


\section{Case Study: Apollo Tyres in Hungary ${ }^{11}$}

Apollo Tyres is also considered to be one of the most significant Indian investors in Hungary. Located less than $100 \mathrm{~km}$ from Budapest, the company's manufacturing site is Apollo Tyres' first greenfield facility outside India, and it was inaugurated in 2017. ${ }^{12}$ The highly automated plant uses IT-driven systems and robotics, employing young and skilled associates, hired mostly from the region. The EUR 475 million worth plant is built over 72 hectares, and the construction began on site in April 2015. The Hungarian facility produces both Apollo and Vredestein brands of tyres for the European market. ${ }^{13}$ Prior to making the decision on a new investment in Central and Eastern Europe, Apollo Tyres already established a manufacturing site in the Netherlands in the late 2000s. However, at the Dutch site, the room for capacity expansion was limited, wherefore the company started to search for a new location of a suitable size and potential for expansion in the long run. Before selecting Hungary as the location in 2014, Apollo was analysing the soft and hard factors of multiple candidate countries. The implementation phase of the project took 24 months, which can be considered as a normal time period for such projects. According to the company, the Hungarian Government, the national investment promotion agency (HIPA), and the local municipality provided all the necessary support throughout the investment project. As for the experiences of Apollo regarding the operation in Hungary, the company considers the availability of labour force to be the major challenge currently. Regarding the legal regulatory environment, the company has mostly positive experiences. In the process of obtaining visa and work permit for Indian colleagues, the company experienced positive changes. Nevertheless, they still see a lot of room for improvement, especially in terms of speed. Apart from this field, the company does not see any major issues regarding the Hungarian regulatory environment.

\section{Tourism}

Undoubtedly, tourism is a sector of great potential. The United Nations World Tourism Organization (UNWTO) estimates that India will account for 50 million outbound tourists by 2020. Despite the slowdown due to rupee fluctuations, the Indian outbound numbers have been growing at an average annual growth rate of $10-12 \%$ over the last seven years up to 2019. In the last seven to eight years, the buying power of Indians has increased along with the Internet and mobile technology, giving thrust to the travel and tourism industry. Indians are now

11 Based on an interview made with a senior manager of Apollo Tyres (Hungary) Ltd. on 24 June 2019.

12 Source: Hungarian Investment Promotion Agency 2017c.

13 See: Hungarian Investment Promotion Agency 2017c 
among the top five spenders for overseas trips (Voyager's World 2019). According to the estimates of the World Travel and Tourism Council, the outbound tourism expenditure of Indians is going to more than double between 2020 and 2030, increasing from USD 26.5 billion to USD 60.5 billion. ${ }^{14}$

Based on a country report published by the Hungarian Tourism Agency in 2017, the number of nights spent by Indian visitors in Hungary has increased by $35.7 \%$ - the highest growth all over Europe (Hungarian Tourism Agency 2017).

On the other hand, in Hungary, India is still considered to be a luxury holiday destination due to the price of air tickets. A direct flight would certainly boost the interest of Hungarian tourists towards India. Nevertheless, the Indian Embassy in Budapest is active in promoting its homeland as a holiday destination for Hungarian travellers. A good example for that was the latest event of the GOA Tourism Road Show held in Budapest in April 2019.

\section{Conclusions}

All those factors mentioned in the paper reflect that there is a lot to do in the field of export. India as an export market is difficult to understand and to explore from the perspective of Hungarian small and medium-sized enterprises. Based on the experiences of Hungarian businesses, similarly to other countries in the East, success in the Indian market requires long-term planning and the investment of substantial amount of time, money, and energy. Only large companies and SMEs with strong foundations can afford and follow this strategy.

Compared to China or Turkey, building business relations with India today receives less political support from the Hungarian Government. Political interactions do not create business opportunities automatically; however, they can boost the cooperation of the private sector as well. Both governments could do a lot more in accelerating the interactions of Hungarian and Indian businesses and creating more possibilities for B2B meetings where opportunities can be identified. To achieve this, Hungarian SMEs would need some sort of governmental support or tender for participating in business events and trade shows in India. On the other hand, business opportunities in India should be promoted in the Hungarian countryside as well.

In many aspects, the Indian business culture is similar to conditions in other eastern countries. Long-term thinking and relationship is essential in building trust and cooperation. Therefore, a local partner can be invaluable for a newcomer western company when entering the market. Nevertheless, it is not easy to identify the relevant business partner that could provide real value and contribution in the process.

14 Source: World Travel and Tourism Council 2019. 
A high level of English language skills in India could be a good basis for enhanced interactions between the business communities of the two countries. Nevertheless, solid trust could only be built through a long period of cooperation.

On the other hand, India is one of the most important Asian investors in Hungary, with a very diverse FDI stock in terms of economic sectors. Indian companies are satisfied with the investment environment in Hungary, which has been proved by several expansion projects in recent years. However, challenges can be identified as well. The competition for the FDI projects of eastern companies is fierce in the region, wherefore the continuous improvement of the business climate is required to maintain the country's attractiveness as an investment location. The number one challenge for Indian investors in Hungary is undoubtedly the availability of labour force. To manage this risk, Indian investment companies corporates with well-established presence in Hungary and newcomers as well have to cooperate closely with the local vocational training schools, universities, and the government itself.

As for outward FDI, the investments of Hungarian corporations in India will surely not solve the unemployment problems of the Asian country. Reasons are manifold and quite obvious: there are only a small group of companies in Hungary that are capable of launching an FDI project abroad and especially outside Central and Eastern Europe, the usual action radius of Hungarian businesses. Differences in culture, climate, and infrastructure standards can also be considered as important pull-back factors.

Despite the shift of gravity in global economy referred to in the introduction of this paper, countries of Western and Central Europe will remain the dominant economic partners of Hungary in the foreseeable future. For sure, India and even China will not replace them in the structure of trade and investment relations. Nevertheless, diversification makes Hungary's external economic relations more stable, and that concerns Eastern orientation as well. An increasing focus on India could make Hungary's Eastern Opening more balanced and less dependent on the results of engagement with China. 


\section{References}

AIRportal.hu. 2014. Egyelőre nem bővít India felé a WizzAir. Retrieved on: 23/09/2019. https://airportal.hu/egyelore-nem-bovit-india-fele-a-wizz-air/.

HUNGARIAN CENTRAL STATISTICAL OFFICE. 2017. A kis- és középvállalkozások helyzete hazánkban. Retrieved on: 23/09/2019. http:// www.ksh.hu/docs/hun/xftp/idoszaki/pdf/kkv16.pdf.

HUNGARIAN GOVERNMENT. 2016. BYD to Realise 20 Million Euro Investment in Komárom. Retrieved on: 17/06/2019. https://www.kormany.hu/en/ministryof-foreign-affairs-and-trade/news/byd-to-realise-20-million-euro-investmentin-komarom.

2017. The Automotive Industry Has Written a 25-Year Success Story in Hungary. Retrieved on: 17/06/2019. http://www.kormany.hu/en/ministryof-foreign-affairs-and-trade/news/the-automotive-industry-has-written-a-25year-success-story-in-hungary.

2018. New Direct Air Passenger Service to Be Launched between Budapest and Mumbai. Retrieved on: 30/04/2019. http://www.kormany.hu/en/ministryof-foreign-affairs-and-trade/news/new-direct-air-passenger-service-to-belaunched-between-budapest-and-mumbai.

HUNGARIAN INVESTMENT PROMOTION AGENCY. 2017a. Tata Consultancy Services and Hungary Committing to the Digital Future. Retrieved on: 17/06/2019. https://hipa.hu/tata-consultancy-services-and-hungarycommitting-to-the-digital-future.

2017b. One of the Largest Greenfield Projects of the Past Years Has Been Delivered in Kecskemét. Retrieved on: 17/06/2019. https://hipa.hu/one-of-thelargest-greenfield-projects-of-the-past-years-has-been-delivered-in-kecskemet. 2017c. Apollo Tyres Inaugurated Their New Plant in Gyöngyöshalász. Retrieved on: 17/06/2019. https://hipa.hu/apollo-tyres-inaugurated-their-new-plant-ingyongyoshalasz.

HUNGARIAN TOURISM AGENCY. 2017. Piaci pillanatfelvétel: India. Retrieved on: 18/04/2019. https://mtu.gov.hu/documents/prod/India_2017.pdf.

MAGYARI, Péter. 2010. Orbán: Keleti szél fúj. Retrieved on: 17/06/2019. https:// index.hu/belfold/2010/11/05/orban_keleti_szel_fuj/.

VOYAGER'S WORLD. 2019. India Travel Trends and Outlook 2019. Retrieved on: 17/03/2019. https://voyagersworld.in/2019/01/22/india-travel-trends-andoutlook-2019/.

WORLD TRAVEL AND TOURISM COUNCIL. 2019. WTTC Data Gateway. Retrieved on: 15/04/2019. http://www.wttc.org/datagateway/. 